\title{
A survey on relationship between intellectual capital and organizational innovation: A case study of banking industry
}

\author{
Gholam Panahandeh and Ahmad Ahmadkhani*
}

Ghavamin Bank, Iran

\section{H R O N I C L E}

Article history:

Received July 28, 2013

Received in revised format

20 November 2013

Accepted 4 January 2014

Available online

February 162014

Keywords:

Intellectual capital

Organizational innovation

Ghavamin bank

\begin{abstract}
A B S T R A C T
This paper presents an empirical investigation to study the relationship between intellectual capital and organizational innovation in an Iranian bank named Ghavamin located in city of Zanjan, Iran. The proposed study uses a questionnaire introduced by Bontis [Bontis, N. (1999). Managing organisational knowledge by diagnosing intellectual capital: framing and advancing the state of the field. International Journal of technology management, 18(5), 433-462.] for measuring the effect of intellectual capital and designs a questionnaire to measure organizational innovation. The questionnaires are distributed among 40 randomly selected managers and regular employees and using Pearson correlation as well as stepwise regression model, the study has detected positive and meaningful relationship between intellectual capital and organizational innovation.
\end{abstract}

(C) 2014 Growing Science Ltd. All rights reserved.

\section{Introduction}

Organization capitals are believed the primary sources of creating innovative ideas and there are many studies on investigating the relationship between these two components (Nahapiet \& Ghoshal, 1998; Tura \& Harmaakorpi, 2005; McElroy, 2002; Nuño-Solinís, 2014; Dieleman, 2013). Delaney and Huselid (1996) investigated the effect of human resource management practices on perceptions of organizational performance. Carmona-Lavado et al. (2010) analyzed the effect of these two dimensions, organizational capital and social capital, on firms' product innovation, and the moderating effect of radicalness among various research and development departments in Spanish industrial companies. They reported that social capital favors firms' product innovation, especially under radical innovations. In addition, organizational capital had an indirect impact on product innovation through positive effect on social capital. This means that firms could stimulate

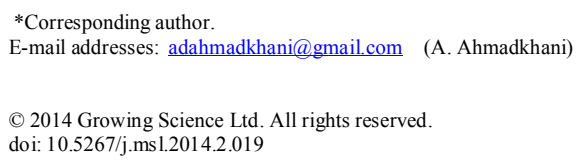


communication and interaction among people, and therefore innovative activity, by tools of explicit and codified knowledge.

Chuang et al. (2013) investigated the relationship between human resource management (HRM) practices and organizational social capital (OSC) and the moderating impacts of industrial characteristics. They reported that HRM practices that concentrate on facilitating relationships among employees were positively associated with OSC, and the relationship was stronger for firms operating in less regulated industries. In addition, knowledge intensity itself indicated no moderating impact but seemed to join industrial regulation in impacting the link of HRM practices and OSC.

Mariz-Perez et al. (2012) investigated the effect of human capital on the innovation capacity of firms. They reported some relevant implications for managers of firms interested in promoting their innovation activity. By considering how human capital was associated with the innovation process. They also tried to provide a useful guide of human capital indicators within the intellectual capital framework. They explained that the primary contribution of their work was the development of a system of indicators for human capital management with the objective of creating for a clear picture of links between strategic human resources and the innovation capacity of firms.

Camisón and Villar-López (2014) evaluated the relationship between organizational innovation and technological innovation capabilities, and investigated their impacts on firm performance using a resource-based view theoretical framework. They reported that organizational innovation favored the development of technological innovation capabilities.

Laforet (2013) investigated organizational innovation outcomes in SMEs. Based on firm interviews and a mail survey, the findings disclosed organizational innovation results in enhanced productivity, margin, market leadership, and working environments. However, OI did not lead to operational efficiency and employees' retention. In their survey, organizational innovation may lead to firms operating outside their core competency but did not have an adverse environmental effect. Organizational innovation had bigger effect on small firms.

Waldorff (2013) investigated the translation of an abstract organizational concept into local organizational innovations. The empirical case was the concept of a health care center, promoted as part of a Danish government reform. The study indicated that municipalities mobilized and interpreted multiple institutional logics to account for their creation of three various organizational innovations.

\section{The proposed study}

This paper presents an empirical investigation to study the relationship between intellectual capital and organizational innovation in an Iranian bank named Ghavamin located in city of Zanjan, Iran. The proposed study uses a questionnaire introduced by Bontis (1999) for measuring the effect of intellectual capital. In addition, the study has designed a questionnaire to measure the effect of human capital. The sample size is as follows,

$$
n=\frac{N \times z_{\alpha / 2}^{2} \times p \times q}{\varepsilon^{2} \times(N-1)+z_{\alpha / 2}^{2} \times p \times q},
$$

where $N$ is the population size, $p=1-q$ represents the yes/no categories, $z_{\alpha / 2}$ is CDF of normal distribution and finally $\varepsilon$ is the error term. Since we have $p=0.5, z_{\alpha / 2}=1.96$ and $N=60$, the number of sample size is calculated as $n=40$. We have used Kolmogrove-Smirnov test and verified that all data 
were normally distributed. Therefore, we may use Pearson correlation test to examine the hypothesis of the survey. The proposed study considers the following main hypothesis as follows,

Main hypothesis: There is a meaningful relationship between intellectual capital and organizational innovation.

There are three sub-hypotheses associated with the proposed study of this paper as follows,

1. There is a meaningful relationship between human capital and organizational innovation.

2. There is a meaningful relationship between structural capital and organizational innovation.

3. There is a meaningful relationship between customer capital and organizational innovation.

\section{The results}

In this section, we present details of our findings on testing the main hypothesis as well as the subhypotheses of the survey. The implementation of Pearson correlation test yields $r=0.78$ with Sig. $=$ 0.000 , which means there is a positive and meaningful relationship between intellectual capital and organizational innovation when the level of significance is one percent. The implementation of Pearson correlation test between organization innovation on one side and human capital, structural capital and customer capital yields $r=0.75, r=0.73$ and $r=0.80$, respectively and they are all meaningful when the level of significance is one percent. We have also performed stepwise regression technique and the results is as follows,

$\begin{array}{cll}\text { Organizational innovation } & =0.54 \text { customer capital }+0.35 \text { human capital } \\ \text { t-student } & 8.90 & 5.26 \mathrm{R}^{2}=0.55 \\ \text { P-value } & 0.000 & 0.001\end{array}$

As we can observe from the regression analysis, there are positive and meaningful relationship between organizational innovation and customer capital $(\beta=0.54)$ and human capital $(\beta=0.35)$. In other words, an increase of one unit in customer capital when other capitals are held constant will increase organizational innovation 0.54 unit. In addition, an increase of one unit in human capital assuming that all other factors are held constant will increase organizational innovation by 0.35 unit.

\section{The results}

In this paper, we have presented an empirical investigation to study the relationship between organizational innovation and human capital. The proposed study has adopted a questionnaire from Bontis (1999) for measuring the effect of intellectual capital and designed a questionnaire for measuring the effect of human capital. Using Pearson correlation ratio as well as Stepwise correlation test, the study has detected positive and meaningful relationship between two components of the survey.

\section{Acknowledgement}

The authors would like to thank anonymous referees for constructive comments on earlier version of this work. 


\section{References}

Bontis, N. (1999). Managing organisational knowledge by diagnosing intellectual capital: framing and advancing the state of the field. International Journal of technology management, 18(5), 433462.

Camisón, C., \& Villar-López, A. (2014). Organizational innovation as an enabler of technological innovation capabilities and firm performance. Journal of Business Research, 67(1), 2891-2902.

Carmona-Lavado, A., Cuevas-Rodríguez, G., \& Cabello-Medina, C. (2010). Social and organizational capital: Building the context for innovation. Industrial Marketing Management, 39(4), 681-690.

Chuang, C. H., Chen, S. J., \& Chuang, C. W. (2013). Human resource management practices and organizational social capital: The role of industrial characteristics. Journal of Business Research, 66(5), 678-687.

Delaney, J. T., \& Huselid, M. A. (1996). The impact of human resource management practices on perceptions of organizational performance. Academy of Management journal, 39(4), 949-969.

Dieleman, H. (2013). Organizational learning for resilient cities, through realizing eco-cultural innovations. Journal of Cleaner Production, 50, 171-180

Laforet, S. (2013). Organizational innovation outcomes in SMEs: Effects of age, size, and sector. Journal of World Business, 48(4), 490-502.

Mariz-Perez, R. M., Teijeiro-Alvarez, M. M., \& Garcìa-Alvarez, M. T. (2012). The relevance of human capital as a driver for innovation. Cuadernos de economía,35(98), 68-76.

McElroy, M. W. (2002). Social innovation capital. Journal of Intellectual Capital, 3(1), 30-39.

Nahapiet, J., \& Ghoshal, S. (1998). Social capital, intellectual capital, and the organizational advantage. Academy of Management Review, 23(2), 242-266.

Nuño-Solinís, R. (2014). Innovación social y organizativa ante el reto de la atención integrada a la cronicidad. Enfermería Clínica, 24(1), 18-22

Tura, T., \& Harmakkorpi, V. (2005). Social capital in building regional innovative capability. Regional Studies, 39(8), 1111-1125.

Waldorff, S. B. (2013). Accounting for organizational innovations: Mobilizing institutional logics in translation. Scandinavian Journal of Management, 29(3), 219-234. 